\title{
Validating anthropogenic threat maps as a tool for assessing river ecological integrity in Andean-Amazon basins
}

\author{
Janeth Lessmann ${ }^{\text {Corresp., } 1,2,3}$, Maria J Troya ${ }^{1}$, Alexander S Flecker ${ }^{4}$, Chris Funk ${ }^{5}$, Juan M Guayasamin ${ }^{1,6}$, Valeria \\ Ochoa-Herrera $^{7}$, N. LeRoy Poff ${ }^{5,8}$, Esteban Suarez ${ }^{1}$, Andrea C Encalada ${ }^{1,9,10}$ \\ 1 Instituto BIÓSFERA, Colegio de Ciencias Biológicas y Ambientales, Universidad San Francisco de Quito, Quito, Ecuador \\ 2 Departamento de Ecología, Pontificia Universidad Católica de Chile, Santiago de Chile, Chile \\ 3 Instituto de Ecología y Biodiversidad, Santiago de Chile, Chile \\ 4 Department of Ecology \& Evolutionary Biology, Cornell University, Ithaca, United States \\ 5 Department of Biology, Graduate Degree Program in Ecology, Colorado State University, Fort Collins, Colorado, United States \\ ${ }^{6}$ Centro de Investigación de la Biodiversidad y Cambio Climático (BioCamb) e Ingeniería en Biodiversidad y Recursos Genéticos, Facultad de Ciencias de \\ Medio Ambiente, Universidad Tecnológica Indoamérica, Quito, Ecuador \\ 7 El Politécnico, Colegio de Ciencias e Ingenierías, Universidad San Francisco de Quito, Quito, Ecuador \\ 8 Institute for Applied Ecology, University of Canberra, Canberra, Australia \\ 9 MARE, Department of Life Sciences, Universidade de Coimbra, Coimbra, Portugal \\ 10 Department of Geography, University of North Carolina at Chapel Hill, Chapel Hill, North Carolina, United States
}

Corresponding Author: Janeth Lessmann

Email address: jdlessmann@uc.cl

Anthropogenic threat maps are commonly used as a surrogate for the ecological integrity of rivers in freshwater conservation, but a clearer understanding of their relationships is required to develop proper management plans at large scales. Here, we developed and validated empirical models that link the ecological integrity of rivers to threat maps in a large, heterogeneous and biodiverse Andean-Amazon watershed. Through fieldwork, we recorded data on aquatic invertebrate community composition, habitat quality, and physical-chemical parameters to calculate the ecological integrity of 140 streams/rivers across the basin. Simultaneously, we generated maps that describe the location, extent, and magnitude of impact of nine anthropogenic threats to freshwater systems in the basin. Through seven-fold cross-validation procedure, we found that regression models based on anthropogenic threats alone have limited power for predicting the ecological integrity of rivers. However, the prediction accuracy improved when environmental predictors (slope and elevation) were included, and more so when the predictions were carried out at a coarser scale, such as microbasins. Moreover, anthropogenic threats that amplify the incidence of other pressures (roads, human settlements and oil activities) are the most relevant predictors of ecological integrity. We concluded that threat maps can offer an overall picture of the ecological integrity pattern of the basin, becoming a useful tool for broad-scale conservation planning for freshwater ecosystems. While it is always advisable 
to have finer scale in situ measurements of ecological integrity, our study shows that threat maps provide fast and cost-effective results, which so often are needed for pressing management and conservation actions. 


\section{Validating anthropogenic threat maps as a tool for}

2 assessing river ecological integrity in Andean-

\section{Amazon basins}

4

5
Janeth Lessmann ${ }^{1,2,3}$, María J. Troya ${ }^{1}$, Alexander S. Flecker ${ }^{4}$, W. Chris Funk ${ }^{5}$, Juan M. Guayasamin $^{1,6}$, Valeria Ochoa-Herrera ${ }^{7}$, N. LeRoy Poff ${ }^{5,8}$, Esteban Suárez ${ }^{1}$, Andrea C. Encalada $1,9,10$

${ }^{1}$ Instituto BIÓSFERA, Colegio de Ciencias Biológicas y Ambientales, Universidad San Francisco de Quito, Quito, Ecuador

2 Departamento de Ecología, Pontificia Universidad Católica de Chile, Santiago de Chile, Chile. ${ }^{3}$ Instituto de Ecología y Biodiversidad, Santiago de Chile, Chile.

${ }^{4}$ Department of Ecology \& Evolutionary Biology, Cornell University, Ithaca, United States.

${ }^{5}$ Department of Biology, Graduate Degree Program in Ecology, Colorado State University, Fort Collins, Colorado, United States.

${ }^{6}$ Centro de Investigación de la Biodiversidad y Cambio Climático (BioCamb) e Ingeniería en Biodiversidad y Recursos Genéticos, Facultad de Ciencias de Medio Ambiente, Universidad Tecnológica Indoamérica, Quito, Ecuador.

${ }^{7}$ El Politécnico, Colegio de Ciencias e Ingenierías, Universidad San Francisco de Quito, Quito, Ecuador.

${ }^{8}$ Institute for Applied Ecology, University of Canberra, Canberra, Australia.

${ }^{9}$ MARE, Department of Life Sciences, University of Coimbra, Coimbra, Portugal.

${ }^{10}$ Department of Geography, University of North Carolina at Chapel Hill, Chapel Hill, North Carolina, United States.

Corresponding Author:

Janeth Lessmann

Departamento de Ecología, Pontificia Universidad Católica de Chile, Alameda 340, Casilla 114D, Santiago 8331150, Chile

Email address: jdlessmann@uc.cl 


\section{Abstract}

43 Anthropogenic threat maps are commonly used as a surrogate for the ecological integrity of

44 rivers in freshwater conservation, but a clearer understanding of their relationships is required to develop proper management plans at large scales. Here, we developed and validated empirical models that link the ecological integrity of rivers to threat maps in a large, heterogeneous and biodiverse Andean-Amazon watershed. Through fieldwork, we recorded data on aquatic invertebrate community composition, habitat quality, and physical-chemical parameters to calculate the ecological integrity of 140 streams/rivers across the basin. Simultaneously, we generated maps that describe the location, extent, and magnitude of impact of nine anthropogenic threats to freshwater systems in the basin. Through seven-fold cross-validation procedure, we found that regression models based on anthropogenic threats alone have limited power for predicting the ecological integrity of rivers. However, the prediction accuracy improved when environmental predictors (slope and elevation) were included, and more so when the predictions were carried out at a coarser scale, such as microbasins. Moreover, anthropogenic threats that amplify the incidence of other pressures (roads, human settlements and oil activities) are the most relevant predictors of ecological integrity. We concluded that threat maps can offer an overall picture of the ecological integrity pattern of the basin, becoming a useful tool for broadscale conservation planning for freshwater ecosystems. While it is always advisable to have finer scale in situ measurements of ecological integrity, our study shows that threat maps provide fast and cost-effective results, which so often are needed for pressing management and conservation actions.

\section{Introduction}

Effective management of large landscape units is an emerging priority for freshwater biodiversity conservation. Several ecosystem processes, the distribution of many species, and the threats they experience occur throughout large geographical areas that often encompass whole watersheds (Collares-Pereira \& Cowx 2004; Thieme et al. 2007). Moreover, the ecological integrity of stream and river ecosystems depends on the connectivity they provide along their courses and across the terrestrial ecosystems with which they interact (Higgins et al. 2005). Therefore, when conservation efforts are conducted at a large watershed scale, maps that represent the spatial variation of the ecological integrity of freshwater systems are a useful tool 
73 to allocate and prioritize conservation resources, and to inform planning for monitoring, and 74 ecosystem-based management (Abell et al. 2002; Carlisle et al. 2009; Clapcott et al. 2011).

75 However, mapping the ecological integrity for these large geographical scales requires extensive 76 and costly fieldwork, hampering our ability to generate the information needed for management 77 (Abell et al. 2002; Revenga et al. 2005). As a result, freshwater ecosystems are often 78 underrepresented in land-use planning and conservation initiatives along large watersheds 79 (Revenga et al. 2005; Comer \& Faber-Langendoen 2013). Here, we develop and test a 80 geographical model to depict the ecological integrity of a large tropical watershed, based on the 81 distribution of human activities at the landscape level.

As an alternative to extensive field assessments of ecological integrity, geographic information systems (GIS) and remote sensing technology can generate and synthesize spatial data on the distribution of human activities (stressors to freshwater ecosystems), that is geographically explicit, and easier to assess and monitor throughout large watersheds (Revenga et al. 2005; Nel et al. 2009). Thus, maps that represent the location and intensity of such stressors (i.e., anthropogenic threat maps) are used in conservation as surrogates for the system's ecological integrity or to make inferences about it (Nel et al. 2009; Linke et al. 2011). For instance, maps on agriculture land use and location of hydroelectric power plants have been used to infer the impairment of ecological integrity in a watershed or adjacent rivers (Thieme et al. 2007; Esselman \& Allan 2011; Finer \& Jenkins 2012; Winemiller et al. 2016; Latrubesse et al. 2017).

Despite the advantages of using anthropogenic threats maps as surrogates of ecological integrity, proper assessments of freshwater ecosystems are critically needed to understand basinwide threat patterns, interactions, and scales of response of ecological integrity (Mattson \& Angermeier 2007; Tulloch et al. 2015). There is high uncertainty regarding the use of coarse and relatively static spatial information on anthropogenic threats to estimate levels of ecological integrity, which is more influenced by local and temporal changes (Clapcott et al. 2011). In addition, important threats to rivers such as discharges of domestic and industrial effluent or the introduction of exotic species, are impossible to detect with remote imagery (O'Neill et al. 1997). Therefore, the field of freshwater conservation needs evaluations to determine if planning based on anthropogenic threat maps, as an indicator of ecological integrity, are reliable and reflect the actual conservation needs of rivers (Clavero et al. 2010). Specifically, we need to 
104 develop empirical models to determine the explanatory power of anthropogenic threat maps for 105 freshwater ecological integrity (Carlisle et al. 2009). Moreover, validating these models with in 106 situ measurements is critical to assess the robustness of anthropogenic threat maps in predicting 107 the conditions of unsampled areas (Carlisle et al. 2009).

108 According to previous studies, the ability of geospatial data on threats to predict 109 ecological integrity can be highly variable (Amis et al. 2007; Carlisle et al. 2009; Clapcott et al. 110 2011; Thornbrugh et al. 2018). Moreover, it is not clear to what extent the accuracy of these 111 predictions is influenced by the set of predictors used in the modeling, the spatial scale of the 112 analysis, and the natural and social context of each study area. For example, land use variables, 113 such as agriculture and urbanization, have been considered crucial predictors due to their 114 considerable impact in regulating stream processes (Allan 2004; Nel et al. 2009). However, 115 considering the high geographic heterogeneity of some regions, the addition of environmental 116 variables and their covariation with anthropogenic gradients could significantly improve the 117 prediction of the ecological integrity (Allan 2004). There is also an increasing interest in the 118 spatial scale at which land use influences stream ecosystem health (Sheldon et al. 2012). Rivers 119 are hierarchically organized systems, in which large-scale characteristics and presence of human 120 threats influence the ecological integrity of watercourses (Oliveira \& Cortes 2006). Thus, the 121 power to predict the ecological integrity for regional-scale units, such as microbasins (i.e., the 122 entire drainage area of a river), might be higher than for local scales (i.e., individual river sites). 123 Finally, for regions with multiple stressors and heterogeneous freshwater systems, the links 124 between ecological integrity and stressors are expected to be difficult to depict (Leal et al. 2016; 125 Schinegger et al. 2016). In this context, the ability of threat maps to infer the health of rivers 126 could be limited. Therefore, studies are needed to assess and validate the circumstances for which predictive models based on anthropogenic threat maps are a useful tool to estimate freshwater ecological integrity and inform management objectives.

The large watersheds that originate in the Andes and give rise to the main tributaries that 130 form the Amazon river are outstanding examples of the ecological, and socio-economic complexities that condition the management of large and heterogeneous landscape units. These

132 basins harbor astonishing levels of freshwater species diversity while providing important 133 services to local populations (Collen et al. 2014). At the same time, human activities such as 134 hydropower development, agricultural expansion, and oil industry are encroaching into these 
135 basins, causing large-scale degradation of freshwater ecosystems (Finer \& Jenkins 2012; Finer et 136 al. 2015; Latrubesse et al. 2017). Given the intimate ecological and hydrological connections

137 between the Andean mountains and Amazonian rivers (Encalada et al. 2019b), proper

138 management and mitigation of these threats require basin-wide monitoring and integrative

139 strategies across their large elevation gradients (Castello \& Macedo 2016). However, the

140 development of such integrative approaches is hindered by the remoteness and topography that

141 characterize these watersheds, their landscape heterogeneity, and the lack of funds to implement

142 ecological monitoring at a large spatial scale (but see (Winemiller et al. 2016; Latrubesse et al.

143 2017). In this context, the development and validation of geographical models depicting the

144 extent, distribution, and impact of anthropogenic threats offers an opportunity to inform future

145 management initiatives at these critical watersheds.

146 In this study, we evaluated the usefulness of an anthropogenic threat map as an index of

147 the ecological integrity of rivers in a key Amazon-Andean watershed: the upper Napo River

148 basin in Ecuador. Specifically, we ask: (1) how well do anthropogenic threat maps predict direct

149 measures of river ecological integrity? (2) which anthropogenic threats and environmental

150 characteristics best explain variation in ecological integrity? and (3) how do predictions differ

151 across spatial scales? For this, we first estimated, via in situ fieldwork, the ecological integrity in

152 several rivers throughout the altitudinal gradient of the basin. Then, we mapped the location,

153 extent, and magnitude of impact of different anthropogenic threats to freshwater ecosystems

154 using geospatial data. Finally, we developed and validated empirical models that link the

155 condition of rivers to spatial information of anthropogenic threats. We also studied the influence

156 of the scale of the analysis unit (local and microbasin), and the use of environmental variables in

157 the predictions. While assessing this tool, our work offers recommendations about the use of

158 anthropogenic threat maps for conservation planning in other Andean-Amazon watersheds,

159 which urgently need expeditious and reliable strategies for management and conservation

160 actions.

161

162

163 Materials \& Methods

164 Study area 
The Napo River basin encompasses an extensive gradient from the summits of the Andes,

166

167

168

169

170

171

172

173

174

175

176

177

178

179

180

181

182

183

184

185

186

187

188

189

190

191

192

193

194

195

to the lowlands of the Amazon. Thus, this basin exhibits exceptional diversity of freshwater species and ecosystems, which competes with an expanding influence of urban settlements, intensive agriculture, oil, mining, and hydroelectric projects (Anderson \& Maldonado-Ocampo 2011; Lessmann et al. 2016a, 2016b). These changes occur in a context in which effective management is hampered by lack of funds and reliable information to detect ongoing ecosystem degradation trends.

In this study, we focused on the $59,573 \mathrm{~km}^{2}$ corresponding to the upper part of the Napo basin, in Ecuador (Fig. 1). The section of the basin we studied ranges from $5897 \mathrm{~m}$ in the Andes, to $200 \mathrm{~m}$ in the Eastern lowlands. The highest slopes of the basin are dominated by páramo ecosystems (i.e., humid mountain steppe composed of shrubs and grasses) and upper montane forests, covering a complex topography and steep slopes that give rise to cold, fast-flowing streams. As they descend into the lower montane forests $(1600-600 \mathrm{~m})$ and approach the Amazonian lowlands $(<600 \mathrm{~m})$, streams become warmer, and wider, eventually turning into large, slow-moving and sediment-loaded lowland rivers. The basin also presents a gradient in human pressures; whereas the eastern Amazonian lowlands contain well conserved ecosystems, the north-central area suffers from the impact of rapid expansion of extractive and agricultural activities and urban development.

\section{Ecological integrity assessment}

To characterize ecological integrity along the upper Napo basin, we established 140 sampling sites (stream width $2-20 \mathrm{~m}$ ) across the altitudinal gradient, from 231 to $3915 \mathrm{~m}$ (Fig. 2). In all cases, we selected sites to represent the heterogeneous characteristics of rivers and anthropogenic pressures found in the area. Sampling was performed between 2011 and 2014. Field permits were granted by The Ecuadorian Ministry of Environment (Permits: \#56-ICFAU/FLO-DPN/MA, MAE-DNB-CM-2015-0017).

Ecological integrity is defined as "the degree to which the physical, chemical and biological components (including composition, structure, and process) of an ecosystem and their relationships are present, functioning and maintained close to a minimally impacted reference condition" (Schallenberg et al. 2001). Although ecological integrity is a widely used concept, the parameters with which it is characterized vary from one ecosystem to another, especially when it 
196 comes to indicator species (Carignan \& Villard 2002). In this study, we assessed the ecological 197 integrity or rivers through three components (Appendix A): (i) stream biotic community

198

199

200

201

202

203

204

205

206

207

208

209

210

211

212

213

214

215

216

217

218

219

220

221

222

223

224

225

226

composition, (ii) habitat integrity, and (iii) water physical-chemical characteristics.

To assess the biotic community composition, at each stream/river site we sampled benthic aquatic invertebrates using Surber samples (5 replicates) and kick samples ( 1 per stream; as in (Gill et al. 2016)). In the laboratory, samples were sorted and classified to the lowest possible taxonomic level following (Domínguez \& Fernández 2009). Then, each identified sample was rated according to its level of physiological tolerance, using the Amazon Biotic Index (AMBI) (Encalada et al. 2019a), which considers a wide pool of invertebrate families from the Andean-Amazon gradient. We also calculated the Average Score Per Taxa (ASPT) (RoldánPérez 1999), which is a parameter that standardizes the AMBI values by the total number of families found in each stream site and represents the biological integrity based on the identity of such families.

We evaluated the habitat quality along each stream/river site through the Riparian Quality Index (QBR-Am) and Fluvial Habitat Index (IHF-Am) (Encalada et al. 2019a). The QBR-Am index evaluates the overall condition of riparian habitat by synthesizing several variables including structure, quality, and species composition of riparian vegetation coverage. On the other hand, IHF-Am incorporates physical and morphological variables such as stream velocity, depth, frequency of riffles/pools/glides, presence of meanders, substrate diversity and composition, and primary producer composition (Pardo et al. 2002). Both indices were modified taking into account the heterogeneous nature of the upper Napo basin (Encalada et al. 2019a).

To evaluate water physical-chemical characteristics, we sampled four key parameters at each river ( $\mathrm{pH}$, conductivity, dissolved oxygen, and temperature). Then, we estimated the deviations from human development by calculating the absolute difference between observed values and references values. These reference values were obtained from Alexiades et al. (2019).

We scaled all parameters (AMBI and ASPT, QBR-Am, IHF-Am, and physical-chemical measurements) between 0 and 1 , with the highest value indicating the highest possible level of ecological integrity for that parameter. These parameters we averaged within their corresponding component. The final step in producing an index was combining the three components into a single value that represents the overall integrity. Here, we used the arithmetic mean because we were interested in producing a straightforward and understandable index, rather than more 
227 sophisticated methods that lose less information but are more unintelligible for conservation 228 planners (Andreasen et al. 2001). Thus, for each river sampled, the Ecological Integrity Index 229 (EII) was obtained by averaging the values of the three components. EII values of 0 indicate the 230 poorest ecological integrity, while values of 1 indicate the highest integrity. We also built an 231 additional metric to contrast the results of the analysis obtained from the arithmetic mean. The 232 biological component can provide a comprehensive measure of ecological integrity because 233 aquatic organisms reflect the cumulative effects of environmental disturbances and pollution 234 (Oliveira \& Cortes 2006). Therefore, for the second metric, we gave more weight to the 235 236

237 238

239

240

241

242

243

244

245

246

247

248

249

250

251

252

253

254

255

256

257 biological component in comparison to the other components (2:1:1) (Andreasen et al. 2001).

\section{Anthropogenic threat maps to freshwater ecosystems}

We generated anthropogenic threat maps for freshwater ecosystems of the upper Napo basin at $482 \mathrm{~m}$ resolution in ArcMap 9.3 (ESRI 2009). Specifically, we evaluated the following threats: human settlements (villages and cities), mining and quarrying (gold, lead), oil activities (wells, oil spills, oil pools and pipelines), hydroelectric and thermoelectric power plants, agricultural land use, water withdrawals, aquaculture farms, and roads (Table 1). These threats have been linked to the ecological integrity of rivers. For example, agriculture, mining, and human settlements are used to infer information on water use, sedimentation, chemical, and nutrient pollution; hydroelectric power and roads can produce hydrologic alterations and fragmentation, and aquaculture farms are related to water pollution and invasive species (Stein et al. 2002; Nel et al. 2009). We gathered digital information on the location and categories that comprise each threat (e.g., types of crops, level of transit on roads, number of inhabitants in cities or villages), from different Ecuadorian institutions. This spatial information was contemporaneous (2012-2013) with the data on ecological integrity collected at the rivers.

We built individual maps for each threat representing its location, extent, and magnitude of impact on the ecological integrity of freshwater systems (McPherson et al. 2008). By consulting specialized references, we assigned a magnitude of impact (from 0 to 1 ) to the different categories within each threat (Table 1). For example, in the case of human settlements, the category of urban areas received a relatively higher impact value (0.65) than villages (0.35). Additionally, we assigned a maximum distance (i.e., buffer) at which a threat category has a negative impact on freshwater ecological integrity, with this impact diminishing linearly within 
258 the buffer (Table 1). When neighboring buffers overlapped, we added the magnitude of their 259 impact. As a result, the nine anthropogenic threats maps summarize the relative magnitude of 260 their impact scaled between 0 and 1 , where 1 represent the maximum level of impact of a threat 261 on freshwater systems.

262

263

Ecological integrity predictive models

264

265

As a first statistical analysis, we executed a Moran Test I (ESRI 2009) to evaluate if ecological integrity levels of sites that lie close to each other were independent. The test 266 indicated that the observed pattern of ecological integrity is consistent with a random distribution

267 ( $\mathrm{Z}$ score 1.55), obviating the need to use statistical methods that deal with spatial autocorrelation 268 (Fortin \& Dale 2005).

Through statistical models (see details below), we estimated the relative importance of

270 each anthropogenic threat as a predictor of the ecological integrity of rivers. Moreover, we tested

271 if the accuracy of these predictions was influenced by the scale of the analysis unit (local vs.

272 regional), and by the inclusion of environmental variables critical for lotic ecosystems.

273 Environmental variables included elevation, slope, water flow accumulation (derived from a

274 digital elevation model, http://srtm.csi.cgiar.org/), and precipitation (from Ministerio del

275 Ambiente del Ecuador 2013). Based on this information, we developed four different modeling

276 scenarios: (a) prediction of local ecological integrity from anthropogenic threat variables alone,

277 (b) prediction of local ecological integrity from anthropogenic threat and environmental 278 variables, (c) prediction of regional ecological integrity from anthropogenic threat variables 279 alone, and (d) prediction of regional ecological integrity from anthropogenic threat and 280 environmental variables. For modeling scenarios at local scales ( $a$ and $b$ ), we used the same unit 281 of analysis as for the anthropogenic threat maps (pixels of $\sim 0.25 \mathrm{~km}^{2}$ ), and we assigned the EII 282 value of each sampled river to the pixel where it occurs. In the case of the modeling scenarios (c) 283 and (d), we classified the basin into 245 microbasins (average size $=243 \mathrm{~km}^{2}, \mathrm{SD}=210$ ), which 284 were derived from a $250 \mathrm{~m}$ digital elevation model, through ARC Hydro tool (ESRI 2009). 285 Values of EII, anthropogenic threats, and environmental variables within a microbasin were 286 averaged, resulting in 29 sampled microbasins in the study area.

287 For each modeling scenario, we fit generalized linear models (GLMs, Gaussian 288 distribution) in R v. 3.1.3 (R Core Team 2014). Using the dredge function implemented in the 
289 MuMIn package (Barton 2009), we started with a global model that contained all explanatory

290 variables, followed by sub-model sets from the global model. In addition, we limited the

291 maximum number of terms in the sub-models to seven in the case of the model scenarios a and $b$

$292(n=140)$, and two for model scenarios $\mathrm{c}$ and $\mathrm{d}(\mathrm{n}=29)$. We selected as the best model the one

293 with lowest AICc (Akaike's information criterion corrected for small sample sizes), excluding

294 models containing collinear predictors (those with correlation Pearson coefficient higher than

295 0.7) (Burnham \& Anderson 2002). The best models selected from the modeling scenarios were

296 used to generate maps that show the predicted ecological integrity at local and regional scales

297 across the entire upper Napo River basin.

298 To obtain a more reliable estimate of the prediction accuracy of ecological integrity,

299 models should be validated with data that are independent of the data used to build the model

300 (Fielding \& Bell 2002). However, as we lack independent data, we used the k-fold cross-

301 validation procedure. In comparison to other methods, the cross validation allows an efficient

302 and unbiased estimation of the predictive power of models by taking average results from $k$

303 partitions of the data (Kuhn \& Johnson 2013). We used the Caret package (Kuhn 2008) to

304 randomly split the data into seven groups of equal size. Then, coefficients of the predictors from

305 the best model were adjusted using the data of the first six groups ( $85 \%$ of observations). The

306 prediction performance $\left(\mathrm{R}^{2}\right)$ of the adjusted model was estimated by comparing the predicted

307 values with the observed values from the seventh group (the $15 \%$ of observations not used to

308 adjust the model). We repeated this procedure 20 times with each group as an evaluation set and

309 the remaining six as a fitting set. The overall predictive performance of the best model was

310 estimated through the mean of all coefficients of determination $\left(\mathrm{R}^{2}\right)$ values from the 20

311 repetitions. Appendix B describes the R routine used to build the predictive models.

312

313

\section{Results}

\section{Sampled ecological integrity and anthropogenic threat maps}

316 Rivers of the upper Napo basin displayed values of ecological integrity ranging from 0.38

317 to 0.90 (Fig. 2 and Appendix C). Although no spatial pattern of ecological integrity was obvious,

318 rivers at higher elevation had the highest number of sites with good ecological integrity $(>0.75$

319 EII). In contrast, rivers with the lowest ecological integrity $(<0.62$ EII) were mostly located 
320 nearby large cities. Moreover, ecological integrity values obtained from the weighted metric 321 (Appendix C) were, in general, lower than those from the arithmetic mean (mean of differences $322=0.05, \mathrm{t}=-12.1, \mathrm{p}<0.0001)$ but displayed the same spatial pattern throughout the basin $(\mathrm{r}=$ $3230.88, \mathrm{p}<0.0001)$.

324

325

326

327

328

329

330

331

332

333

334

335

336

337

338

339

340

341

342

343

344

345

346

347

348

349

350

According to the anthropogenic threat maps (Fig. 3), threats with the greatest extent in the basin were agricultural land use ( $52 \%$ of the basin), human settlements (21\%), mining (15\%), and oil activities $(10 \%)$. In contrast, the impact of power plants, water withdrawals, and aquaculture farms was more spatially limited. Furthermore, we observed that several anthropogenic features (agricultural land use, mining, oil activities, aquaculture farms) were restricted to areas near roads, especially in the lowlands.

\section{Predictive models of ecological integrity}

Based on the cross-validation analysis (Table 2), we found that the best models from each modeling scenarios differed in their predictive ability. There was limited power to predict ecological integrity at a local scale using only anthropogenic threat variables as predictors (model a: mean $\mathrm{R}^{2}=0.16, \mathrm{SD}=0.14$ ). However, the prediction accuracy of modeling at a local scale improved with the inclusion of environmental variables (model b: mean $\mathrm{R}^{2}=0.23, \mathrm{SD}=$ 0.16 ), and more so if we carried out the analyses at a regional scale (model $\mathrm{c}$ and $\mathrm{d}$ : mean $\mathrm{R}^{2}=$ $0.47, \mathrm{SD}=0.32$ ). Notice that environmental variables were not part of the best models at the regional scale, and therefore the results of modeling scenarios $\mathrm{c}$ and $\mathrm{d}$ are the same.

Regarding the predictor variables, roads and human settlements were often selected in the best models (and several sub-optimal models), indicating that rivers near roads, cities, and villages have lower ecological integrity (Table 2). The presence of oil industry activities was also associated with lower levels of ecological integrity at a local scale. Slope and elevation were also selected at a local scale, having a positive and negative relationship with ecological integrity, respectively. Sub-optimal models are available in Appendix D. Best models based on the EII constructed with weighted metric has slightly lower predictive powers than models based on the arithmetic mean. However, models for both metrics showed similar relationships between ecological integrity and predictors (Appendix D).

Although the modeling scenarios differed in terms of predictive power, predictor variables, and spatial scales, the general spatial patterns of predicted ecological integrity was 
351 similar (Fig. 4): (1) main roads and large cities predicted poor river conditions (<0.62 EII), (2)

352 remote areas of Amazonian lowlands, which have little presence of anthropogenic threats were

353 projected to have high integrity (>0.70 EII), and (3) when environmental variables were

354 included, rivers in the Andean foothills were predicted to have a very high ecological integrity

355 (>0.80 EII).

356

357

\section{Discussion}

359

360

361

362

363

364

365

366

367

368

369

370

371

372

373

374

375

376

377

378

379

380

381

Understanding the geographical pattern of the anthropogenic threats and their spatial relationships with ecological integrity of rivers is a basic but often neglected aspect of freshwater conservation planning (Clavero et al. 2010). Since anthropogenic threat maps are assumed to be a good proxy of the condition of freshwater ecosystems (Linke et al. 2011), they are used in conservation planning at regional scales that may involve prioritization for protection of rivers with a good ecological condition over disturbed and expensive rivers to manage or restore (Neeson et al. 2016; Linke et al. 2019). Nevertheless, the success of such planning depends on how effective threat maps are as a surrogate of the ecological condition of rivers. From this perspective, our study is the first to analyze spatial information on anthropogenic threats to freshwater ecosystems and its relationship with ecological integrity across an Andean-Amazon basin. With this contribution, we validate an approach (i.e., threat maps generated by GIS) to inform conservation planning at a regional scale in the upper Napo basin and in other basins of the region that face similar environmental challenges such as the Marañon, Ucayali, and Putumayo basins.

How well do anthropogenic threat maps predict the ecological integrity?

Our study found that the ecological integrity of rivers and microbasins of the upper Napo basin tends to decrease with increasing anthropogenic threats. Although our regression models showed modest power for predicting the integrity of unsampled rivers and microbasins (between $\mathrm{R}^{2} 0.16$ and $\mathrm{R}^{2}$ 0.47), other studies for large and diverse regions have found a similar predictive ability of ecological integrity based on spatial data on human threats. For Amazonian low-order streams, between $10 \%$ and $35 \%$ of the variation in habitat measures were explained by maps of anthropogenic and environmental predictors (Leal et al. 2016). For United States watersheds, 
382 spatial data on stressors accounted for $1-12 \%$ of the variation in site-level biological and habitat 383 variables of streams (Thornbrugh et al. 2018). According to these studies, the heterogeneous 384 nature of the stream systems, multiple stressors, and different land-use histories in these regions 385 hinder our ability to depict the relationships between maps of human threats and ecological 386 integrity patterns (Buecker et al. 2010; Leal et al. 2016; Schinegger et al. 2016). Therefore, it is

387 388 389 390 391

392 393 394

395 396 397 398 399 400 401

402 403

404 405 406 407 408 409 410 411 412 reasonable to find modest predictive power for the upper Napo basin models (Thornbrugh et al. 2018). Despite these constraints, our results confirm that direct ecological-integrity measures of rivers in this basin are tied to anthropogenic pressures that were independently derived from spatial data. This finding is especially encouraging since both indices (EII and threats maps) represent a drastic reduction in information content. Therefore, our study supports the use of threat maps to provide a coarse representation of actual conditions of rivers throughout the upper Napo basin, with explicit acknowledgment of the associated uncertainty.

Which anthropogenic threats and environmental variables best explain the ecological integrity of rivers?

Our study identified roads as a relevant predictor of river's integrity in the upper Napo River basin. The specific impact of roads to rivers has been considered to be low when compared to more detrimental human activities, such as agriculture or mining (Cooper 2011; Esselman \& Allan 2011). However, as shown in the threat maps, human settlements, agricultural activities, water consumption, and mining appear clustered near roads (Fig. 3). This pattern suggests that roads are associated with the presence of other threats to ecological integrity, indirectly linking roads to integrity. Given the rough and steep terrain that dominates large portions of this basin, the roads that can be established tend to run through the more accessible areas, thus concentrating the spatial distribution of other threats such as agriculture (Suárez et al. 2012).

According to our models, human settlements and oil activities are also relevant predictors of river's ecological integrity. In the Amazon basin, cities and villages are associated with high deforestation rates, which alter the habitat integrity of rivers. Human settlements also increase erosion, runoff of waters with contaminants (oil, heavy metals, pesticides, sediment, nutrients, pathogens), and discharges of untreated effluents from domestic and industrial activities to nearby rivers (Celi 2005; Alho et al. 2015). Oil-related activities in the AndeanAmazon basins have received enormous attention due to the frequent cases of malpractice and oil 
413 spills that affect the health of rivers (Fontaine 2003). Moreover, oil activities in the Andean-

414 Amazon region have historically encouraged the proliferation of other human pressures, such as 415 roads and agricultural expansion (Suárez et al. 2009, 2012).

416 The strength of our predictive models increased significantly when environmental 417 variables were mapped and used to estimate ecological integrity with anthropogenic threats.

418 Specifically, sites with greater slopes have better ecological integrity, which results from two 419 combined factors. First, steep slopes lead to rivers with riffles and rapids, allowing them to 420 regain healthier ecosystem qualities in areas affected by human activity (Rosgen 1994; Newbury 421 2013). Second, steep areas may constrain the expansion of human economic activities, whereas 422 resources that are economically-valuable, such as oil reserves and oil palm plantations, are found 423 in the Amazonian floodplains (Celi 2005). A negative relationship between elevation and 424 ecological integrity was also found in our models, which is explained by the large number of 425 remote lowland areas in the basin that have a low presence of threats.

How do predictions differ across spatial scales?

428 Including environmental variables in the models improved their explanatory power, but a 429 considerable part of the variation in ecological integrity at a local scale remains unexplained. As 430 expected, ecological integrity measured in situ varied greatly among nearby rivers because of 431 site-specific, short-term changes (e.g., flooding events), and localized human-related changes 432 (e.g., riparian vegetation loss, overfishing) (Allan et al. 1997; Arthington et al. 2004). In contrast, 433 anthropogenic threat data do not reflect the most recent and local changes. Thus, the predictive 434 capacity of models improved when the unit of analysis was transformed to microbasins (regional 435 scale), and the spatial scale of both, response and predictor variables were the same. Moreover, 436 processes such as sediment load, nutrient supply, hydrology, and channel characteristics are 437 influenced by the landscape and upstream conditions, which were better captured by analyses at 438 a regional scale rather than local scale (Allan et al. 1997; Arthington et al. 2004). 
444 that threat maps are a valid resource for coarse-filter conservation planning in the upper Napo

445 basin and other Andean-Amazon basins where measures of the condition of rivers are absent or 446 prohibitively expensive to collect. We also found this mapping approach is especially effective at 447 depicting the impacts of human activities that facilitate the incidence of other threats. For 448 example, the effect of roads, settlements, and oil activities, which were significant predictors in 449 our model, is probably mediated through the combined influence of several human activities 450 associated with these predictors.

451 The use of anthropogenic threat maps for freshwater conservation planning has 452 limitations that are important to acknowledge. First, anthropogenic threat maps have different 453 caveats according to the spatial scale of the conservation actions. Since the explanatory power of 454 the models at a local scale is limited, it would always be advisable to have a finer scale in situ 455 measurements of ecological integrity for conservation or restoration projects focused on specific 456 target rivers. Models at the microbasin (regional) scale, although more explanatory, do not offer 457 estimates of the ecological integrity at specific rivers within basins. Therefore, reliable use of 458 anthropogenic threat maps is, for example: prioritizing which un-sampled micro-watershed 459 require targeted assessments, searching for reference rivers in areas were high ecological 460 integrity is predicted, or identifying sites that will need monitoring programs because of the 461 expected increase in oil, urban, and road development in the basin. influenced by the indicators used to assess the condition of the river. For example, in our study, ecological integrity was not inferred by hydroelectric power plants, despite of their growing and significant impact on connectivity of Andean-Amazon rivers (Winemiller et al. 2016; Anderson et al. 2018). However, this impact is localized for small invertebrates with limited dispersal capabilities, but massive for vertebrates that depend on the longitudinal connectivity provided by 468 rivers. Therefore, management initiatives that favor this mapping approach must combine assessments of other threats that consider longitudinal, lateral, and temporal connectivity in the watershed (Winemiller et al. 2016; Anderson et al. 2018). Another example of the relevance of 471 the indicators of ecological integrity was the limited role of the oil activities that we found in our 472 modeling. Such result could be explained by the fact that our ecological integrity index does not 473 consider hydrocarbon, metallic elements, and other oil-related chemicals in the water, which 474 might constraint the sensitivity of our index. 
475

476

477

478

479

480

481

482

483

484

485

486

\section{Conclusions}

488

489

490

491

492

493

494

495

496

497

498

499

500

501

503

\section{Conclusions}

\section{1}

\section{2 \\ Acknowledgements}

504 Laboratory at Universidad San Francisco de Quito and Universidad Tecnológica Indoamérica.

505 We thank the Cayambe-Coca Ecological Reserve and the village of Oyacachi for access to sites;

Finally, there is also room for improving investigations on the link between threat maps and the condition of Andean-Amazon rivers. Even though our study was based on extensive fieldwork, sample sites were not always evenly distributed along the whole gradient of stressors, such as aquaculture farms and hydroelectric, which might explain the week response of ecological integrity to these stressors (Schinegger et al. 2016). Improving the sampling to better represent the gradient and different combinations of stressors would help disentangle single and joint effects (Schinegger et al. 2016). In addition, our study assumed a simple scenario where the effects of threats to the ecological integrity were a negative linear response (Thornbrugh et al. 2018). However, an improved sampling could additionally help to elucidate if the relationships between stressors and ecological integrity better fit a non-linear function. rivers? This is a central question for freshwater conservation planners, who usually lack resources for carrying out extensive field surveys along landscapes. In this context, our study found the prediction accuracy of ecological integrity is reasonable high when environmental factors are added to the threat maps as predictors, and when the analysis are carried out at regional scales. These results have broad applications for planners, which could make use of such maps as a first step for coarse prioritizations of conservation and management actions. However, for further actions at finer scales, target rivers should be subjected to more detailed evaluations in order to have site-level measurements of the integrity and local stressors. Thus, the knowledge gained by this study offers insights into the usefulness and limitations of anthropogenic threat maps and helps with the prioritization of conservation and management actions at a regional scale in the Andean-Amazon basins.

Data gathering and processing was a collaboration of members of the Aquatic Ecology 
506 the people of Oyacachi for field assistance. We also thank Maja Celinscak, Eduardo Toral, Nathy 507 Quiroz, Luis Granizo, José Schreckinger, Rommel Arboleda, Jaime Culebras, and Ítalo Tapia for 508 the field assistance. The following institutions of Ecuador provided spatial information on 509 anthropogenic threats in the Napo basin: The Nature Conservancy, Instituto Nacional de 510 Estadística y Censos, Agencia de Regulación y Control Minero, Agencia de Regulación y 511 Control de Electricidad, Programa Socio Bosque and Secretaria del Agua. We are very grateful 512 to all people and institutions mentioned above.

513

514

515

\section{References}

517 Abell R, Thieme M, Dinerstein E, Olson D. 2002. A Sourcebook for Conducting Biological

518

519

520

521

522

523

524

525

526

527

528

529

530

531

532

533

534

535

536 Assessments and Developing Biodiversity Visions for Ecoregion Conservation. Volumen II. Freshwater Ecoregions. World Wildlife Fund, DC, USA.

Alexiades AV, Encalada AC, Lessmann J, Guayasamin JM. 2019. Spatial prediction of stream physicochemical parameters for the Napo River Basin, Ecuador. Journal of Freshwater Ecology 34:249-263.

Alho CJR, Reis RE, Aquino PPU. 2015. Amazonian freshwater habitats experiencing environmental and socioeconomic threats affecting subsistence fisheries. Ambio 44:412425.

Allan D, Erickson D, Fay J. 1997. The influence of catchment land use on stream integrity across multiple spatial scales. Freshwater Biology 37:149-161.

Allan JD. 2004. Landscapes and Riverscapes: The Influence of Land Use on Stream Ecosystems. Annual Review of Ecology, Evolution, and Systematics 35:257-284. Annual Reviews.

Amis MA, Rouget M, Balmford A, Thuiller W, Kleynhans CJ, Day J, Nel J. 2007. Predicting freshwater habitat integrity using land-use surrogates. Water Sa 33:215-221.

Anderson EP et al. 2018. Fragmentation of Andes-to-Amazon connectivity by hydropower dams. Science Advances 4.

Anderson EP, Maldonado-Ocampo JA. 2011. A Regional Perspective on the Diversity and Conservation of Tropical Andean Fishes. Conservation Biology 25:30-39.

Andreasen JK, O'Neill R V, Noss R, Slosser NC. 2001. Considerations for the development of a 
537

538

539

540

541

542

543

544

545

546

547

548

549

550

551

552

553

554

555

556

557

558

559

560

561

562

563

564

565

566

567

terrestrial index of ecological integrity. Ecological Indicators 1:21-35.

Arthington A, Lorenzen K, Pusey BJ, Abell R, Halls AS, Winemiller KO, Arrington DA, Baran E. 2004. River fisheries: ecological basis for management and conservation. Page (Petr RLW and T, editor) Proceedings of the second International Symposium on the Management of Large Rivers for Fisheries Volume 1. Food and Agriculture Organisation of the United Nations.

Barton K. 2009. MuMIn: multi-model inference. R package, version 0.12.2.

Buecker A, Sondermann M, Frede H-G, Breuer L. 2010. The influence of land-use on macroinvertebrate communities in montane tropical streams - a case study from Ecuador. Fundamental and Applied Limnology 177:267-282.

Buschmann A. 2001. Impacto Ambiental de la Acuicultura: El Estado de Investigación en Chile y en el Mundo. Terram Publicaciones, Santiago, Chile.

Carignan V, Villard MA. 2002. Selecting indicator species to monitor ecological integrity: A review. Environmental Monitoring and Assessment 78:45-61.

Carlisle DM, Falcone J, Meador MR. 2009. Predicting the biological condition of streams: Use of geospatial indicators of natural and anthropogenic characteristics of watersheds. Environmental Monitoring and Assessment 151:143-160.

Castello L, Macedo MN. 2016. Large-scale degradation of Amazonian freshwater ecosystems. Global Change Biology 22:990-1007.

Celi J. 2005. The vulnerability of aquatic systems of the Upper Napo river basin (Ecuadorian Amazon) to human activities. Florida International University, Miami, Florida.

Clapcott JE, Young RG, Goodwin E, Leathwick JR, Kelly D. 2011. Relationships between multiple land-use pressures and individual and combined indicators of stream ecological integrity. Department of Conservation. DOC Research and Development Series 326, Wellington.

Clavero M, Hermoso V, Levin N, Kark S. 2010. Geographical linkages between threats and imperilment in freshwater fish in the Mediterranean Basin. Diversity and Distributions 16:744-754.

Collares-Pereira MJ, Cowx IG. 2004. The role of catchment scale environmental management in freshwater fish conservation. Fisheries Management and Ecology 11:303-312.

Collen B, Whitton F, Dyer EE, Baillie JEM, Cumberlidge N, Darwall WRT, Pollock C, Richman 
568 NI, Soulsby A-M, Böhm M. 2014. Global patterns of freshwater species diversity, threat 569 and endemism. Global Ecology and Biogeography 23:40-51.

570 Comer PJ, Faber-Langendoen D. 2013. Assessing Ecological Integrity of Wetlands From

571 National to Local Scales: Exploring the Predictive Power, and Limitations, of Spatial

572 Models. National Wetlands Newsletter 35:20-22.

573 Cooper S. 2011. A GIS-based water quality risk assessment of Thompson Region watersheds.

574 Ministry of Environment, British Columbia.

575 Domínguez E, Fernández HR. 2009. Macroinvertebrados bentónicos sudamericanos: sistemática 576 y biología. Fundación Miguel Lillo, Tucumán, Argentina.

577 Encalada AC et al. 2019a. Los ríos de las cuencas Andino-Amazónicas: Herramientas y guía de 578 invertebrados para el diseño efectivo de programas de monitoreo. Trama, Quito, Ecuador. 579 Encalada AC, Flecker AS, Poff NL, Suárez E, Herrera-R GA, Ríos-Touma B, Jumani S, Larson 580 EI, Anderson EP. 2019b. A global perspective on tropical montane rivers. Science 365:1124 $581 \quad$ LP -1129.

582 ESRI. 2009. ArcMap 9.3. ESRI, Redlands, California.

583 Esselman PC, Allan JD. 2011. Application of species distribution models and conservation

584

585

586

587

588

589

590

591

592

593

594

595

596

597

598

planning software to the design of a reserve network for the riverine fishes of northeastern Mesoamerica. Freshwater Biology 56:71-88.

Fielding AH, Bell JF. 2002. A review of methods for the assessment of prediction errors in conservation presence/absence models. Environmental Conservation 24:38-49.

Finer M, Babbit B, Novoa S, Ferrarese F, Pappalardo SE, De Marchi M, Saucedo M, Kumar A. 2015. Future of oil and gas development in the western Amazon. Environmental Research Letters 10:24003.

Finer M, Jenkins CN. 2012. Proliferation of Hydroelectric Dams in the Andean Amazon and Implications for Andes-Amazon Connectivity. PLoS ONE 7:e35126.

Fontaine G. 2003. Petróleo y desarrollo sostenible en Ecuador: Reglas de juego. FLACSO \& GPA Petroecuador, Quito.

Fortin M-J, Dale MRT. 2005. Spatial Analysis: A Guide for Ecologists. Cambridge University Press, Cambridge.

González del Tánago M. 1996. Impacto de la agricultura en los sistemas fluviales: Técnicas de restauración para la conservación del suelo y del agua. Agricultura y Sociedad 78:211-236.

PeerJ reviewing PDF | (2019:03:36227:1:1:NEW 15 Oct 2019) 
599 Higgins J V, Bryer MT, Khoury ML, Fitzhugh TW. 2005. A Freshwater Classification Approach 600 for Biodiversity Conservation Planning. Conservation Biology 19:432-445.

601 Kuhn M. 2008. Caret: Classification and Regression Training. R package version 6.0-71.

602 Kuhn M, Johnson K. 2013. Applied Predictive Modeling. Springer, New York, USA.

603 Latrubesse EM et al. 2017. Damming the rivers of the Amazon basin. Nature 546:363-369.

604 Leal CG et al. 2016. Multi-scale assessment of human-induced changes to Amazonian instream 605 habitats. Landscape Ecology 31:1725-1745.

606 Lessmann J et al. 2016a. Freshwater vertebrate and invertebrate diversity patterns in an Andean607 Amazon basin: implications for conservation efforts. Neotropical Biodiversity 2:99-114.

608 Lessmann J, Fajardo J, Muñoz J, Bonaccorso E. 2016b. Large expansion of oil industry in the 609 Ecuadorian Amazon: biodiversity vulnerability and conservation alternatives. Ecology and 610 Evolution 6.

611 Linke S, Hermoso V, Januchowski-Hartley S. 2019. Toward process-based conservation 612 prioritizations for freshwater ecosystems. Aquatic Conservation: Marine and Freshwater 613 Ecosystems 29:1149-1160. John Wiley \& Sons, Ltd.

614 Linke S, Turak E, Nel J. 2011. Freshwater conservation planning: the case for systematic 615 approaches. Freshwater Biology 56:6-20. John Wiley \& Sons, Ltd (10.1111).

616 Mattson KM, Angermeier PL. 2007. Integrating Human Impacts and Ecological Integrity into a 617 Risk-Based Protocol for Conservation Planning. Environmental Management 39:125-138.

618 McPherson M, Schill S, Raber G, John K, Zenny N, Thurlow K, Sutton AH. 2008. GIS-based 619 modeling of Environmental Risk Surfaces (ERS) for conservation planning in Jamaica. 620 Journal of Conservation Planning 4:60-89.

621 Neeson TM, Smith SDP, Allan JD, McIntyre PB. 2016. Prioritizing ecological restoration among 622 sites in multi-stressor landscapes. Ecological Applications 26:1785-1796. John Wiley \& 623 Sons, Ltd.

624 Nel JL, Roux DJ, Abell R, Ashton PJ, Cowling RM, Higgins J V, Thieme M, Viers JH. 2009. 625 Progress and challenges in freshwater conservation planning. Aquatic Conservation: Marine 626 and Freshwater Ecosystems 19:474-485. John Wiley \& Sons, Ltd.

627 Newbury R. 2013. Rivers and the Art of Stream Restoration. Pages 137-149 in J. E. Costa, A. J. 628 Miller, K. W. Potter, and P. R. Wilcock, editors. Natural and Anthropogenic Influences in 629 Fluvial Geomorphology. American Geophysical Union. 
630 O’Neill R V, Hunsaker CT, Jones KB, Riitters KH, Wickham JD, Schwartz PM, Goodman IA, 631 Jackson BL, Baillargeon WS. 1997. Monitoring Environmental Quality at the Landscape 632 Scale. BioScience 47:513-519.

633 O'Rourke D, Connolly S. 2003. Just oil? The distribution of environmental and social impacts of 634 oil production and consumption. Annual Review of Environment and Resources 28:587$635 \quad 617$.

636 Oliveira SV, Cortes RMV. 2006. Environmental indicators of ecological integrity and their 637 development for running waters in northern Portugal. Limnetica 25:479-498.

638 Pardo I, Alvarez M, Moreno JL, Vivas S, Bonada N, Alba-Terecedor J, Jaimez-Cuellar P, Moya 639 G, Prat N, Robles N, Vidal-Abarca MR. 2002. El habitat de los ríos mediterráneos. Diseño 640 de un índice de diversidad de habitat. Limnetica 21:115-134.

641 R Core Team. 2014. R: A language and environment for statistical computing. R Foundation for $642 \quad$ Statistical Computing, Vienna, Austria.

643 Revenga C, Campbell I, Abell R, de Villiers P, Bryer M. 2005. Prospects for monitoring 644 freshwater ecosystems towards the 2010 targets. Philosophical Transactions of the Royal 645 Society B-Biological Sciences 360:397-413.

646 Roldán-Pérez G. 1999. Los macroinvertebrados como bioindicadores de la calidad del agua.

647 Revista de la Academia Colombiana de Ciencias Exactas, Físicas y Naturales 23:375-387.

648 Romero FM, Armienta MA, Gutiérrez ME, Villasenor G. 2008. Factores geológicos y climáticos 649 que determinan la peligrosidad y el impacto ambiental de jales mineros. Revista 650 internacional de contaminación ambiental 24.

651 Rosenfeld AB, Gordon DL, Guerin-McManus M. 1997. Reinventing the well. Approaches to 652 minimizing the environmental and social impact of oil development in the Tropics.

653 Conservation International, USA.

654 Rosgen DL. 1994. A classification of natural rivers. Catena 22:169-199.

655 San Sebastian M, Hurtig A. 2004. Oil exploitation in the Amazon basin of Ecuador: a public 656 health emergency. Pan Am J Publ Health 15:205-211.

657 Schallenberg M, Kelly D, Clapcott J, Death R, MacNeil C, Young B, Sorrell B, Scarsbrook M. 658 2001. Approaches to assessing ecological integrity of New Zealand freshwaters. Page 659 Science for Conservation 307. Department of Conservation, Wellington.

660 Schinegger R, Palt M, Segurado P, Schmutz S. 2016. Untangling the effects of multiple human 
661

662

663

664

665

666

667

668

669

670

671

672

673

674

675

676

677

678

679

680

681

682

683

684

685

686

687

688

689

690

691

stressors and their impacts on fish assemblages in European running waters. Science of The Total Environment 573:1079-1088.

Sheldon F, Peterson EE, Boone EL, Sippel S, Bunn SE, Harch BD. 2012. Identifying the spatial scale of land use that most strongly influences overall river ecosystem health score. Ecological Applications 22:2188-2203. John Wiley \& Sons, Ltd.

Stein JL, Stein JA, Nix HA. 2002. Spatial analysis of anthropogenic river disturbance at regional and continental scales: identifying the wild rivers of Australia. Landscape and Urban Planning 60:1-25.

Suárez E, Morales M, Cueva R, Utreras Bucheli V, Zapata-Ríos G, Toral E, Torres J, Prado W, Vargas Olalla J. 2009. Oil industry, wild meat trade and roads: indirect effects of oil extraction activities in a protected area in north-eastern Ecuador. Animal Conservation 12:364-373.

Suárez E, Zapata-Ríos G, Utreras V, Strindberg S, Vargas J. 2012. Controlling access to oil roads protects forest cover, but not wildlife communities: a case study from the rainforest of Yasuní Biosphere Reserve (Ecuador). Animal Conservation 16:265-274.

Thieme M, Lehner B, Abell R, Hamilton SK, Kellndorfer J, Powell G, Riveros JC. 2007. Freshwater conservation planning in data-poor areas: An example from a remote Amazonian basin (Madre de Dios River, Peru and Bolivia). Biological Conservation 135:484-501.

Thornbrugh DJ, Leibowitz SG, Hill RA, Weber MH, Johnson ZC, Olsen AR, Flotemersch JE, Stoddard JL, Peck D V. 2018. Mapping watershed integrity for the conterminous United States. Ecological Indicators 85:1133-1148.

Tiwary RK. 2001. Environmental impact of coal mining on water regime and its management. Water Air and Soil Pollution 132:185-199.

Tulloch VJD, Tulloch AIT, Visconti P, Halpern BS, Watson JEM, Evans MC, Auerbach NA, Barnes M, Beger M, Chadès I, Giakoumi S, McDonald-Madden E, Murray NJ, Ringma J, Possingham HP. 2015. Why do we map threats? Linking threat mapping with actions to make better conservation decisions. Frontiers in Ecology and the Environment 13:91-99.

Verones F, Hanafiah MM, Pfister S, Huijbregts MAJ, Pelletier GJ, Koehler A. 2010. Characterization Factors for Thermal Pollution in Freshwater Aquatic Environments. Environmental Science \& Technology 44:9364-9369. American Chemical Society. 
692 Winemiller KO, McIntyre PB, Castello L, Fluet-Chouinard E, Giarrizzo T, Nam S, Baird IG, 693 Darwall W, Lujan NK, Harrison I, Stiassny MLJ, Silvano RAM, Fitzgerald DB, Pelicice 694 FM, Agostinho AA, Gomes LC, Albert JS, Baran E, Petrere M, Zarfl C, Mulligan M, 695 Sullivan JP, Arantes CC, Sousa LM, Koning AA, Hoeinghaus DJ, Sabaj M, Lundberg JG, 696 Armbruster J, Thieme ML, Petry P, Zuanon J, Vilara GT, Snoeks J, Ou C, Rainboth W, 697 Pavanelli CS, Akama A, Soesbergen A van, Sáenz L. 2016. Balancing hydropower and 698 biodiversity in the Amazon, Congo, and Mekong. Science 351:128-129. 


\section{Table $\mathbf{1}$ (on next page)}

Table 1. Values of the magnitude of impact and the impact distance used to construct anthropogenic threat maps for freshwater systems in the upper Napo River basin.

We collected spatial data on human threats directly from government ministries and NGOs following official information requests. The assignment of magnitude of impact and distance values was a logical process informed by the literature and our knowledge of the study area. 


\begin{tabular}{|c|c|c|c|c|c|c|}
\hline Anthropogenic threat & \multicolumn{2}{|c|}{ Categories within threats } & $\begin{array}{l}\text { Magnitude of } \\
\text { impact }\end{array}$ & $\begin{array}{l}\text { Impact } \\
\text { distance }\end{array}$ & Source & $\begin{array}{l}\text { References used for } \\
\text { assigning the magnitude } \\
\text { and distance of impact }\end{array}$ \\
\hline \multirow{2}{*}{$\begin{array}{l}\text { Human settlements } \\
\text { (scaled between } 0-1 \\
\text { according to human } \\
\text { density) }\end{array}$} & \multicolumn{2}{|l|}{ Urban areas } & 0.65 & $10 \mathrm{~km}$ & \multirow{2}{*}{$\begin{array}{l}\text { Instituto Geográfico Militar. } 2012 . \\
\text { Base Regional, 1:250.000 } \\
\text { (http://www.igm.gob.ec/). } \\
\text { Instituto Nacional de Estadística y } \\
\text { Censos. Densidad poblacional. } 2012 . \\
\text { (http://www.ecuadorencifras.gob.ec/) }\end{array}$} & \multirow{2}{*}{$\begin{array}{l}\text { Magnitude: Stein et al. } \\
\text { (2002); McPherson et al. } \\
\text { (2008); Esselman \& Allan } \\
\text { (2011) } \\
\text { Distance: McPherson et al. } \\
\text { (2008); Esselman \& Allan } \\
\text { (2011) }\end{array}$} \\
\hline & \multicolumn{2}{|l|}{ Village } & 0.35 & $3 \mathrm{~km}$ & & \\
\hline \multirow{3}{*}{ Mining } & \multicolumn{2}{|c|}{ Construction material mining } & 0.6 & \multirow{3}{*}{$5 \mathrm{~km}$} & \multirow{3}{*}{$\begin{array}{l}\text { Agencia de Regulación y Control } \\
\text { Minero. 2012. Mapa del Catastro } \\
\text { Minero Nivel Nacional. 1:1.400.000 } \\
\text { (http://www.controlminero.gob.ec/) } \\
\text { The Nature Conservancy of Ecuador. } \\
\text { 2013. }\end{array}$} & \multirow{3}{*}{$\begin{array}{l}\text { Magnitude: Tiwary (2001); } \\
\text { Stein et al. (2002); } \\
\text { McPherson et al. (2008); } \\
\text { Romero et al. (2008) } \\
\text { Distance: Stein et al. } \\
\text { (2002); McPherson et al. } \\
\text { (2008) }\end{array}$} \\
\hline & \multicolumn{2}{|c|}{ Metal mining } & 0.4 & & & \\
\hline & \multicolumn{2}{|c|}{ Non-metal mining } & 0.1 & & & \\
\hline \multirow{2}{*}{ Agricultural land use } & \multicolumn{2}{|c|}{$\begin{array}{l}\text { Permanent, semi-permanent, and } \\
\text { annual crops }\end{array}$} & 0.6 & & Socio Bosques. Estimación de la Tasa & $\begin{array}{l}\text { Magnitude: González del } \\
\text { Tánago (1996); Stein et al. } \\
\text { (2002); McPherson et al. }\end{array}$ \\
\hline & \multicolumn{2}{|c|}{ Agricultural mosaic and pastureland } & 0.4 & & (http://sociobosque.ambiente.gob.ec/) & $\begin{array}{l}\text { Distance: McPherson et al. } \\
\text { (2008) }\end{array}$ \\
\hline \multirow{6}{*}{$\begin{array}{l}\text { Hydroelectric power } \\
\text { plants (size based on } \\
\text { generated power) }\end{array}$} & \multirow{3}{*}{ Operating } & Large size & 0.375 & \multirow{6}{*}{$\begin{array}{l}\text { Scaled to } \\
\text { plant size } \\
\text { (max. } 30 \\
\text { km) }\end{array}$} & \multirow{6}{*}{$\begin{array}{l}\text { Agencia de Regulación y Control de } \\
\text { Electricidad. } 2012 . \\
\text { (http://www.regulacionelectrica.gob.e } \\
\text { c/) } \\
\text { The Nature Conservancy of Ecuador. } \\
2013 .\end{array}$} & \multirow{6}{*}{$\begin{array}{l}\text { Magnitude: Stein et al. } \\
\text { (2002); Finer \& Jenkins } \\
\text { (2012) } \\
\text { Distance: McPherson et al. } \\
\text { (2008) }\end{array}$} \\
\hline & & Medium size & 0.225 & & & \\
\hline & & Small size & 0.15 & & & \\
\hline & \multirow{3}{*}{$\begin{array}{l}\text { Under } \\
\text { construction }\end{array}$} & Large size & 0.125 & & & \\
\hline & & Medium size & 0.075 & & & \\
\hline & & Small size & 0.05 & & & \\
\hline $\begin{array}{l}\text { Thermoelectric power } \\
\text { plants }\end{array}$ & Without cate & & 1 & $2 \mathrm{~km}$ & $\begin{array}{l}\text { Agencia de Regulación y Control de } \\
\text { Electricidad. } 2012 . \\
\text { (http://www.regulacionelectrica.gob.e } \\
\text { c/) }\end{array}$ & $\begin{array}{l}\text { Distance: adapted from } \\
\text { Stein et al. (2002); } \\
\text { Verones et al. (2010) }\end{array}$ \\
\hline
\end{tabular}




\begin{tabular}{|c|c|c|c|c|c|c|}
\hline \multirow{11}{*}{ Oil activities } & \multirow{2}{*}{ Wells } & Operating & 0.28 & \multirow[t]{2}{*}{$1.5 \mathrm{~km}$} & \multirow{11}{*}{$\begin{array}{l}\text { Sistema Nacional de Información de } \\
\text { la Reparación Integral. Mapa de } \\
\text { afectaciones ambientales. } 2012 \text {. } \\
\text { (http://pras.ambiente.gob.ec/siesap), } \\
\text { The Nature Conservancy of Ecuador. } \\
2013\end{array}$} & \multirow{11}{*}{$\begin{array}{l}\text { Magnitude: Rosenfeld et } \\
\text { al. (1997); Stein et al. } \\
\text { (2002); O'Rourke \& } \\
\text { Connolly (2003); San } \\
\text { Sebastian \& Hurtig (2004) } \\
\text { Distance: Stein et al. } \\
\text { (2002) }\end{array}$} \\
\hline & & No operating & 0.07 & & & \\
\hline & \multirow{2}{*}{ Recent oil spills } & High volume & 0.15 & \multirow{7}{*}{$5 \mathrm{~km}$} & & \\
\hline & & Low volume & 0.09 & & & \\
\hline & Old oil anills & High volume & 0.075 & & & \\
\hline & Old oll spills & Low volume & 0.015 & & & \\
\hline & \multirow{3}{*}{ Oil pools } & Without treatment & 0.2 & & & \\
\hline & & $\begin{array}{l}\text { Recent with } \\
\text { treatment }\end{array}$ & 0.0625 & & & \\
\hline & & $\begin{array}{l}\text { Old without } \\
\text { treatment }\end{array}$ & 0.0125 & & & \\
\hline & \multirow{2}{*}{ Pipeline } & $\begin{array}{l}\text { In risky areas (e.g. } \\
\text { landslides) }\end{array}$ & 0.07 & \multirow{2}{*}{$30 \mathrm{~m}$} & & \\
\hline & & Out of risk areas & 0.03 & & & \\
\hline Aquaculture farms & \multicolumn{2}{|l|}{ Without categories } & $\begin{array}{l}\text { Scaled from } 0.1 \\
\text { to } 1 \text { according to } \\
\text { water volume }\end{array}$ & $1 \mathrm{~km}$ & $\begin{array}{l}\text { Secretaría del Agua. } 2013 . \\
\text { (http://www.agua.gob.ec/) }\end{array}$ & $\begin{array}{l}\text { Distance: Buschmann } \\
\text { (2001); Stein et al. (2002) }\end{array}$ \\
\hline Water withdrawals & \multicolumn{2}{|l|}{ Without categories } & $\begin{array}{l}\text { Scaled from } 0.1 \\
\text { to } 1 \text { according to } \\
\text { water volume }\end{array}$ & $1 \mathrm{~km}$ & $\begin{array}{l}\text { Secretaría del Agua. } 2013 . \\
\text { (http://www.agua.gob.ec/) }\end{array}$ & $\begin{array}{l}\text { Distance: adapted from } \\
\text { McPherson et al. (2008) }\end{array}$ \\
\hline \multirow{3}{*}{ Roads } & \multicolumn{2}{|l|}{ Primary road } & 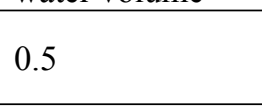 & \multirow{3}{*}{$1 \mathrm{~km}$} & \multirow{3}{*}{$\begin{array}{l}\text { Instituto Geográfico Militar. } 2012 . \\
\text { Base Regional, 1:250.000 } \\
\text { (http://www.igm.gob.ec/). }\end{array}$} & \multirow{2}{*}{$\begin{array}{l}\text { Magnitude: Stein et al. } \\
\text { (2002); McPherson et al. } \\
\text { (2008); Esselman \& Allan } \\
\text { (2011) }\end{array}$} \\
\hline & \multicolumn{2}{|l|}{ Secondary road } & 0.3 & & & \\
\hline & \multicolumn{2}{|l|}{ Local road } & 0.2 & & & $\begin{array}{l}\text { Distance: Stein et al. } \\
\text { (2002); Celi (2005) }\end{array}$ \\
\hline
\end{tabular}

1 


\section{Table 2 (on next page)}

Table 2. Best models for predicting the ecological integrity index (EII) in four different modeling scenarios (a-d).

All predictor variables, included environmental factors, were scaled between $0-1$ 
1 Table 2. Best models for predicting the ecological integrity index (EII) in four different 2 modeling scenarios (a-d). All predictor variables, included environmental factors, were scaled 3 between $0-1$.

4

\begin{tabular}{|c|c|c|c|}
\hline Modeling scenarios & Selected variables & Coefficients & $\begin{array}{l}\text { Mean } \mathrm{R}^{2} \text { (from } \\
\text { cross-validation) }\end{array}$ \\
\hline $\begin{array}{l}\text { a. River EII prediction, with } \\
\text { threat variables }(\mathrm{N}=140)\end{array}$ & $\begin{array}{l}\text { Intercept } \\
\text { Human settlements } \\
\text { Roads } \\
\text { Oil activities }\end{array}$ & $\begin{array}{l}0.738 * * * \\
-0.145 * \\
-0.080 \\
-0.106\end{array}$ & 0.16 (SD 0.14) \\
\hline $\begin{array}{l}\text { b. River EII prediction, with } \\
\text { threat and environmental } \\
\text { variables }(\mathrm{N}=140)\end{array}$ & $\begin{array}{l}\text { Intercept } \\
\text { Human settlements } \\
\text { Roads } \\
\text { Oil activities } \\
\text { Elevation } \\
\text { Slope }\end{array}$ & $\begin{array}{l}0.762 * * * \\
-0.165 * \\
-0.121 * * \\
-0.136 * \\
-0.176 * * * \\
0.199 * * *\end{array}$ & $0.23(\mathrm{SD} 0.16)$ \\
\hline $\begin{array}{l}\text { c. EII prediction with threat } \\
\text { variables }(\mathrm{N}=29)\end{array}$ & $\begin{array}{l}\text { Intercept } \\
\text { Roads }\end{array}$ & $\begin{array}{l}0.767 * * * \\
-1.576 * * *\end{array}$ & 0.47 (SD 0.32) \\
\hline $\begin{array}{l}\text { d. Microbasin EII prediction } \\
\text { with threat and environmental } \\
\text { variables }(\mathrm{N}=29)\end{array}$ & $\begin{array}{l}\text { Intercept } \\
\text { Roads }\end{array}$ & $\begin{array}{l}0.767 * * * \\
-1.576 * * *\end{array}$ & 0.47 (SD 0.32) \\
\hline
\end{tabular}




\section{Figure 1}

Figure 1. Study area.

The upper Napo River basin is an Andean-Amazon watershed in Ecuador with a large altitudinal gradient and heterogeneous freshwater systems. 


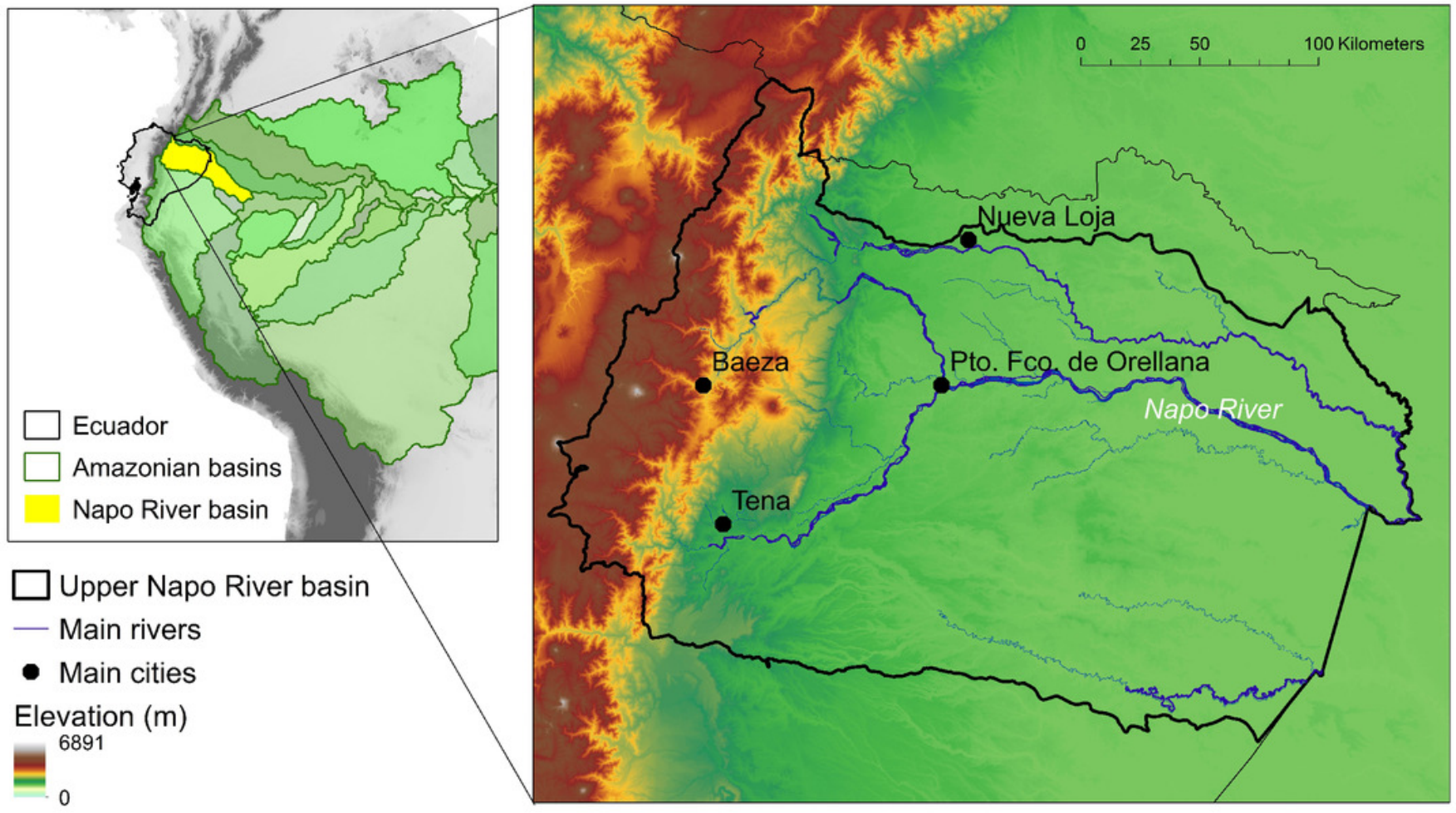


Figure 2

Figure 2. Ecological integrity index (EII) for all sampled rivers in the upper Napo River basin.

Low values of Ell (red color) indicate rivers with the poorest ecological integrity, whereas rivers with Ell values near 1 (dark blue color) indicate the highest integrity. 


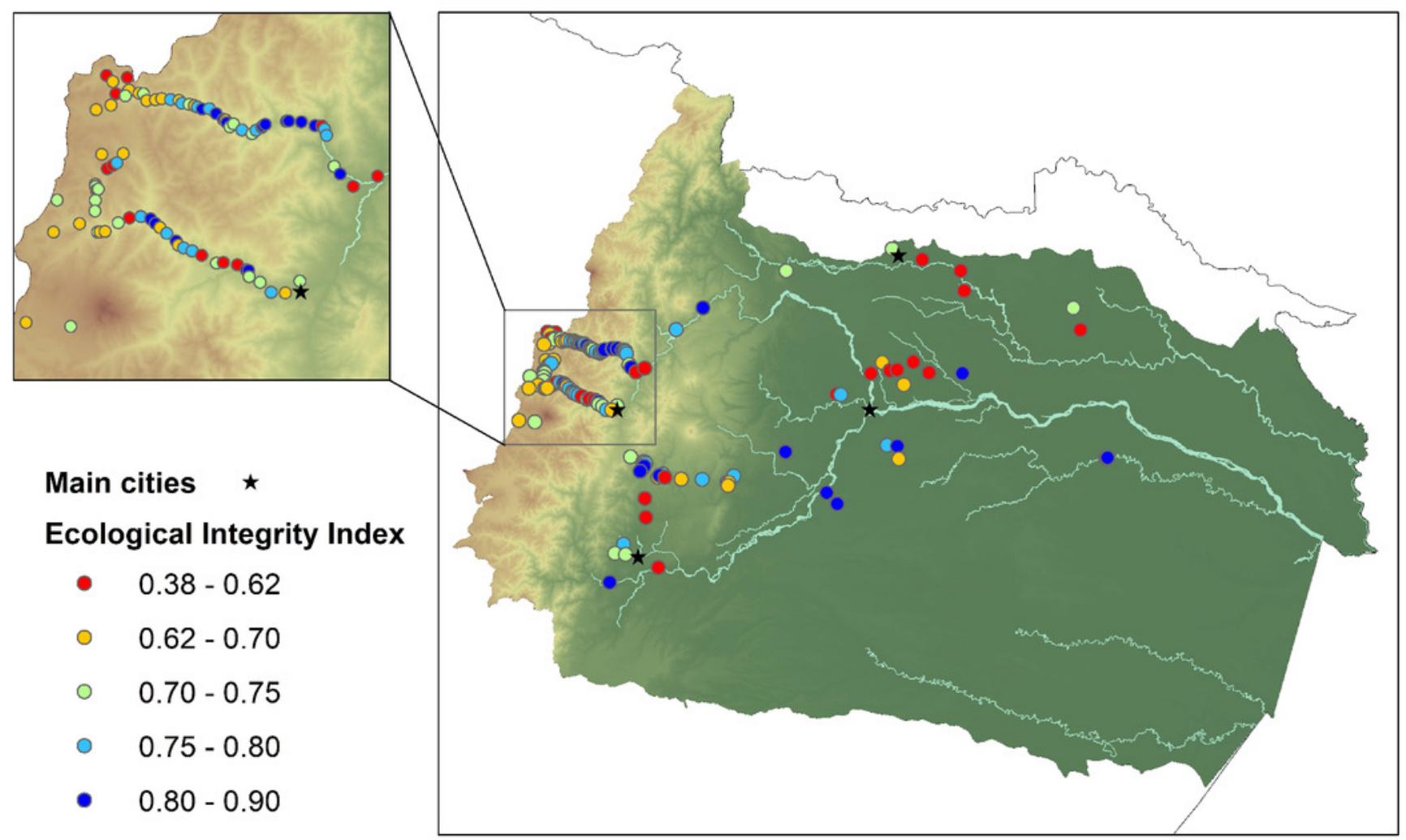




\section{Figure 3}

Figure 3. Anthropogenic threat maps for freshwater ecosystems in the upper Napo River basin.

The magnitude of impact of each threat ranges between 0 and 1 . Values closer to 1 are sites where a given threat has the maximum impact to freshwater systems. In contrast, an impact value of 0 represents sites with no records of such pressures. Evaluated anthropogenic threats were: (A) human settlements, (B) mining, (C) agricultural land use, (D) hydroelectric power plants, (E) thermoelectric power plants, (F) oil activities, $(G)$ water withdrawals, $(H)$ aquaculture farms, and (I) roads. 

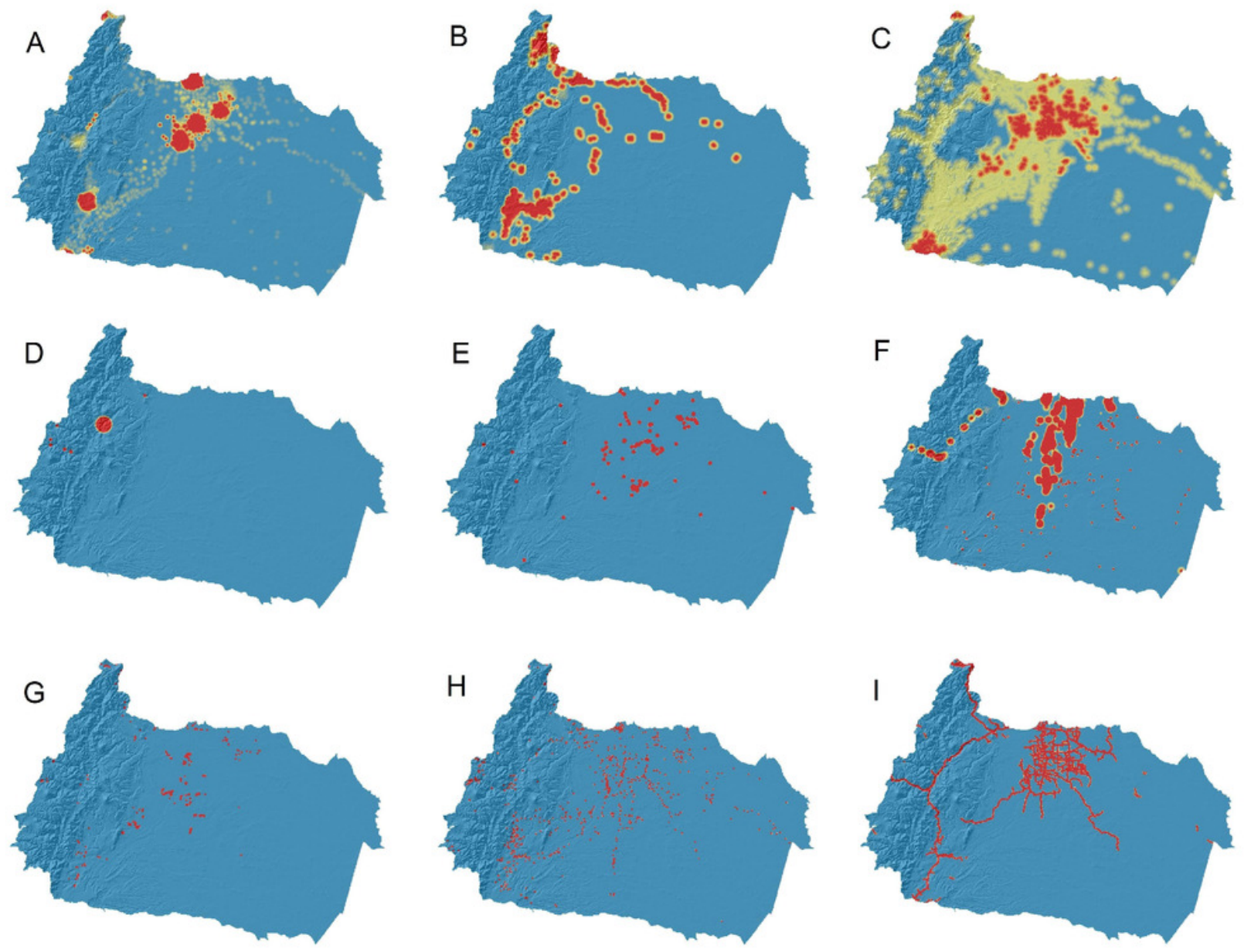

\section{Anthropogenic threats}

Magnitude of impact

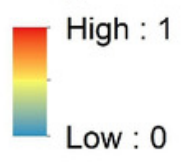




\section{Figure 4}

Figure 4. Predicted ecological integrity for freshwater systems in the upper Napo River basin.

Maps of predicted ecological integrity are results of different modeling scenarios: (a) prediction of local ecological integrity from anthropogenic threat variables alone, (b) prediction of local ecological integrity from anthropogenic threat and environmental variables, (c) prediction of microbasin ecological integrity from anthropogenic threat variables alone, and from anthropogenic threat and environmental variables. 


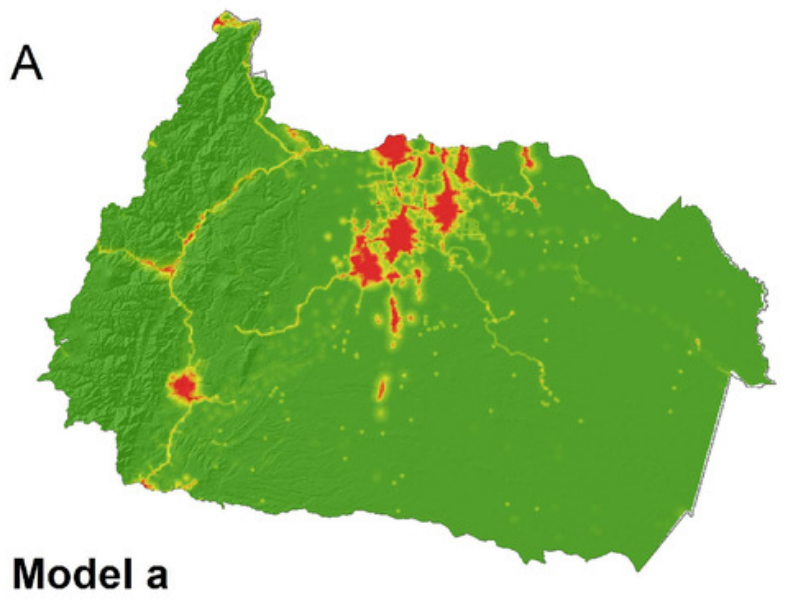

Ecological integrity values

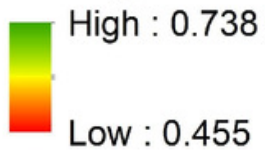

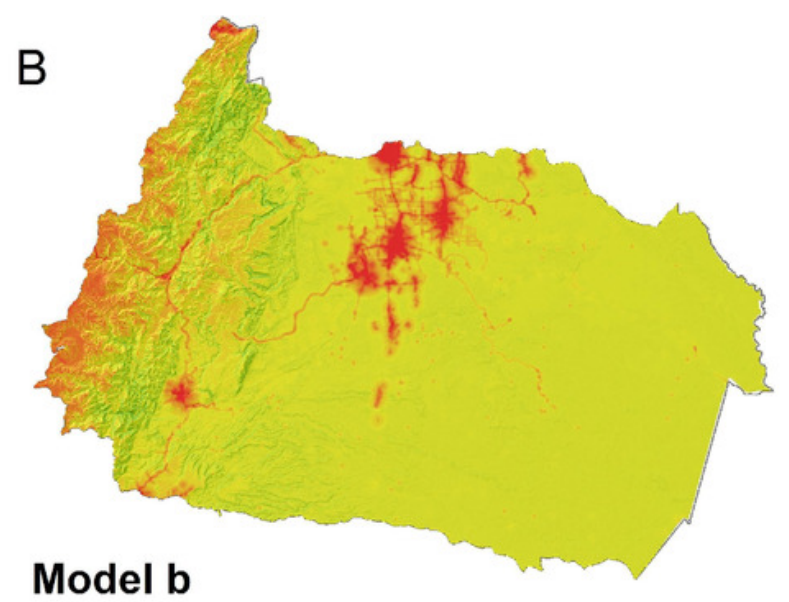

Ecological integrity values

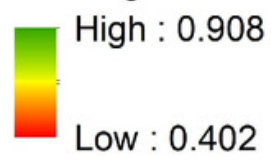

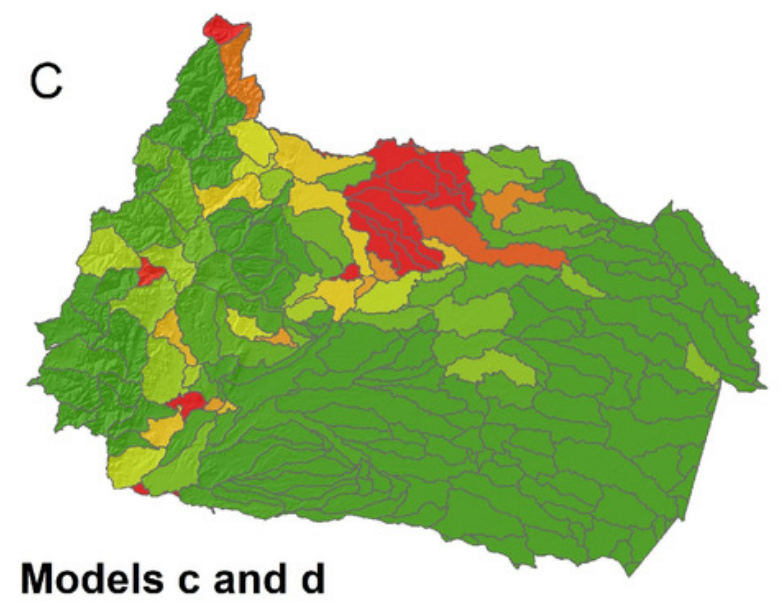

Ecological integrity values

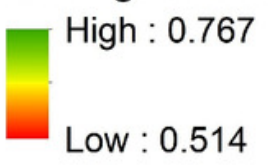

